\title{
Consumer Satisfaction Analysis of Seafood Processed Products
}

\author{
Achmad Rizal $^{1}$, William Cheung ${ }^{2}$, Asep Agus Handaka Suryana ${ }^{3}$, Atikah Nurhayati ${ }^{4}$ \\ Center for social-economic of fishery studies, Faculty of Fisheries and Marine Sciences, \\ Universitas Padjajaran, Indonesia ${ }^{1234}$
}

\begin{abstract}
This study aims to determine the attributes that affect the level of customer satisfaction and the value of the level of customer satisfaction in the Bandar Djakarta restaurant of Alam Sutera of Tangerang City. The method used in this study is the method of importance-performance analysis to determine the attributes that affect customer satisfaction and the customer satisfaction index to determine the value of overall customer satisfaction. After all the data has been processed, the data will be analyzed descriptively. The technique used to take samples in this study is accidental sampling. Sampling was carried out for four weeks in July 2019 with a total of 85 respondents. The results of this study indicate that the attributes that make consumers feel satisfied are the variety of food, product taste, food hygiene, safety guarantees, the hospitality of the waitress, queuing time, room comfort and room cleanliness. While the attributes that make consumers feel less satisfied are the cleanliness of eating utensils and the speed at which food is served. The overall value of customer satisfaction is at 85,00 .
\end{abstract}

Keyword. attributes; customer; satisfaction.

Article history. Received August, 2019. Revised October, 2019. Accepted December, 2019

Corresponding author. achmad.rizal@unpad.ac.id

How to cite article. Rizal, A., Cheung, W., Agus, A., Suryana, H., \& Nurhayati, A. (2019). Consumer Satisfaction Analysis of Seafood Processed Products. The International Journal of Business Review (The Jobs Review), 2(2), 173-181. https://doi.org/https://doi.org/10.17509/tjr.v2i2.19710

\section{INTRODUCTION}

Seafood is one of the favorite foods for the people of Indonesia. One seafood restaurant that is quite famous in the Jabodetabek area is Bandar Djakarta. Bandar Djakarta itself already has several branches in Jabodetabek such as Ancol, Alam Sutera, Bekasi, and Pluit. This restaurant is already quite famous and has quite several rivals in the Jabodetabek area. Bandar Djakarta itself is one of the biggest seafood restaurants in South Tangerang.

Bandar Djakarta is demanded to be able to understand the desires or expectations of consumers to create satisfaction for consumers. The services provided by Bandar Djakarta are very satisfying on weekdays. But when it is on holidays or Saturdays and Sundays, the services provided are less than satisfactory because consumers/visitors are very crowded. Some of the problems discovered during the survey were waiters who only used sign language to consumers, too full seating and the delay in the arrival of dishes that were ordered. Therefore it is necessary to have an assessment and analysis of customer satisfaction in Bandar Djakarta to ensure that consumers who come will make repeat purchases and recommend this restaurant to others or close family. The purpose of this research is to know (1) Analyze the attributes that most influence consumer satisfaction in Bandar Djakarta Restaurant and (2) Analyzing the level of customer satisfaction Bandar Bandar Jakarta restaurant. 


\section{METHOD}

The method used is the case study method. Primary data were obtained from interviews and questionnaires to respondents. the sampling technique used was an accidental sampling method. Accidental sampling technique is a sampling technique based on the chance that is the consumer who meets with the researcher and is considered suitable as a source of data. This research was conducted at Bandar Djakarta Restaurant, Alam Sutera, Tangerang. Data collection will take place on July 2019. This research is divided into four phases, namely the first, second, third and fourth week

The data analysis method used in this research is the quantitative descriptive method, the data obtained are analyzed descriptively presented in tables, writing, diagrams or graphs. Descriptive analysis is a form of analysis of research data to describe or analyze the results of research, not used to make broader conclusions. Descriptive analysis is used to determine the characteristics of consumers to consumer satisfaction through the calculation of the percentage of the number of respondents presented in the form of a simple tabulation. Data Analysis that conducted on this research are:

\section{Importance of Performance Analysis}

Importance performance analysis is an analytical tool that illustrates the performance of a product compared to consumer expectations of the performance that should exist (Rizal and Nurruhwati, 2019). Performance appraisal that can influence respondent satisfaction is contained by letter X, while the importance assessment is indicated by letter Y. To measure the level of importance and level of company performance the Likert scale is used.

The results of the calculation will be described in a matrix called the Importance Performance Matrix. Each attribute is positioned in the matrix based on the average score, where the average score of importance rating (Yr) shows the position of an attribute in the $\mathrm{Y}$-axis, while the average score of performance level evaluation (Xr) indicates the position of an attribute on the axis $\mathrm{X}$. The formula to be used is.

$\mathrm{X}_{\mathrm{r}}=\frac{\sum X}{n}$

$\mathrm{Y}_{\mathrm{r}}=\frac{\sum Y}{n}$

\section{Customer Satisfaction Index}

Customer satisfaction index used to determine the level of overall customer satisfaction by looking at the level of restaurant product or service attributes. There are four stages to measuring this index (Gujarati, 2004; Rizal et.al., 2017)

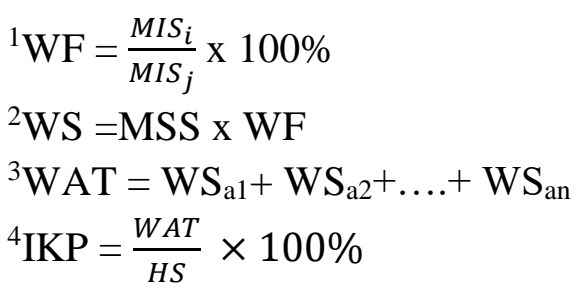

\section{RESULTS AND DISCUSSION}

\section{Consumer characteristics}


The characteristics of Bandar Djakarta restoring consumers discussed in this study include gender, age, occupation, number of family members, domicile area and monthly income. Each consumer has different characteristics and ratings, but the restaurant as a whole must be able to know the characteristics of consumers - consumers, therefore it is necessary to know the general characteristics of consumers who come in Bandar Djakarta restaurants.

The number of respondents whose male is 46 respondents. The number of respondents whose female is 39 respondents.

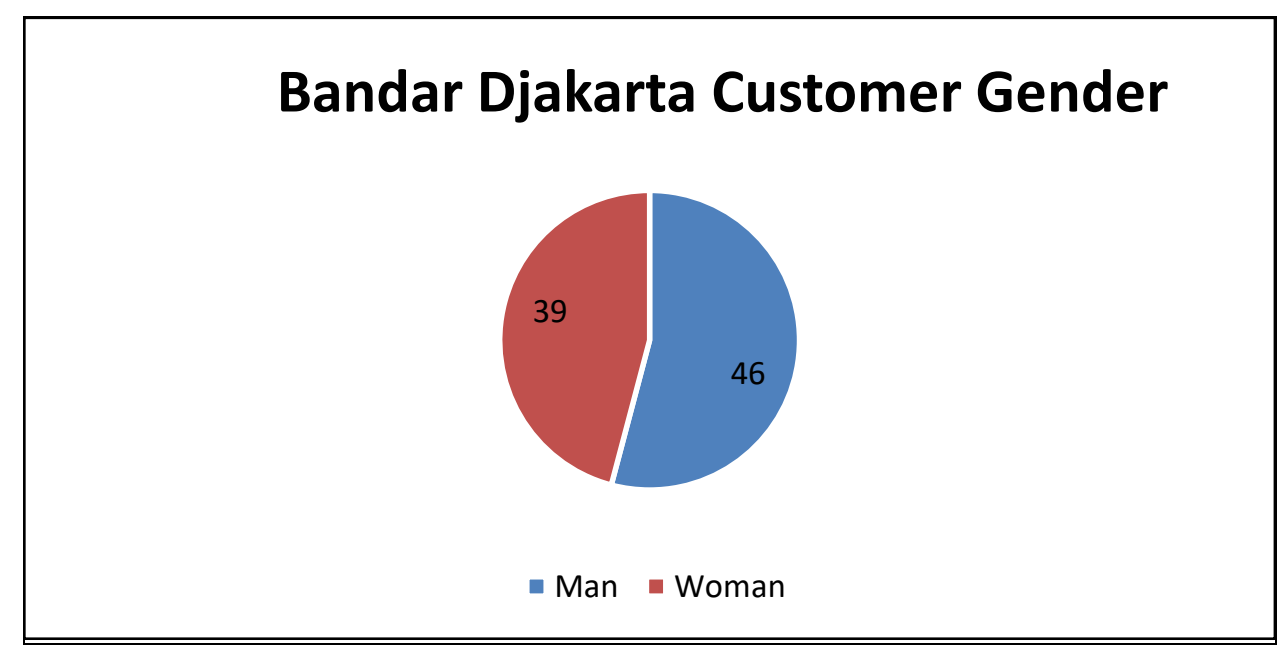

Figure 1. Consumer characteristics based on gender

The age range of 21-30 years is the majority in this study because it has the highest number of respondents but only 1 respondent differs from a class that has an age range of 31-40 years. This means that the majority of Djakarta city consumers are aged between 21-40 years.

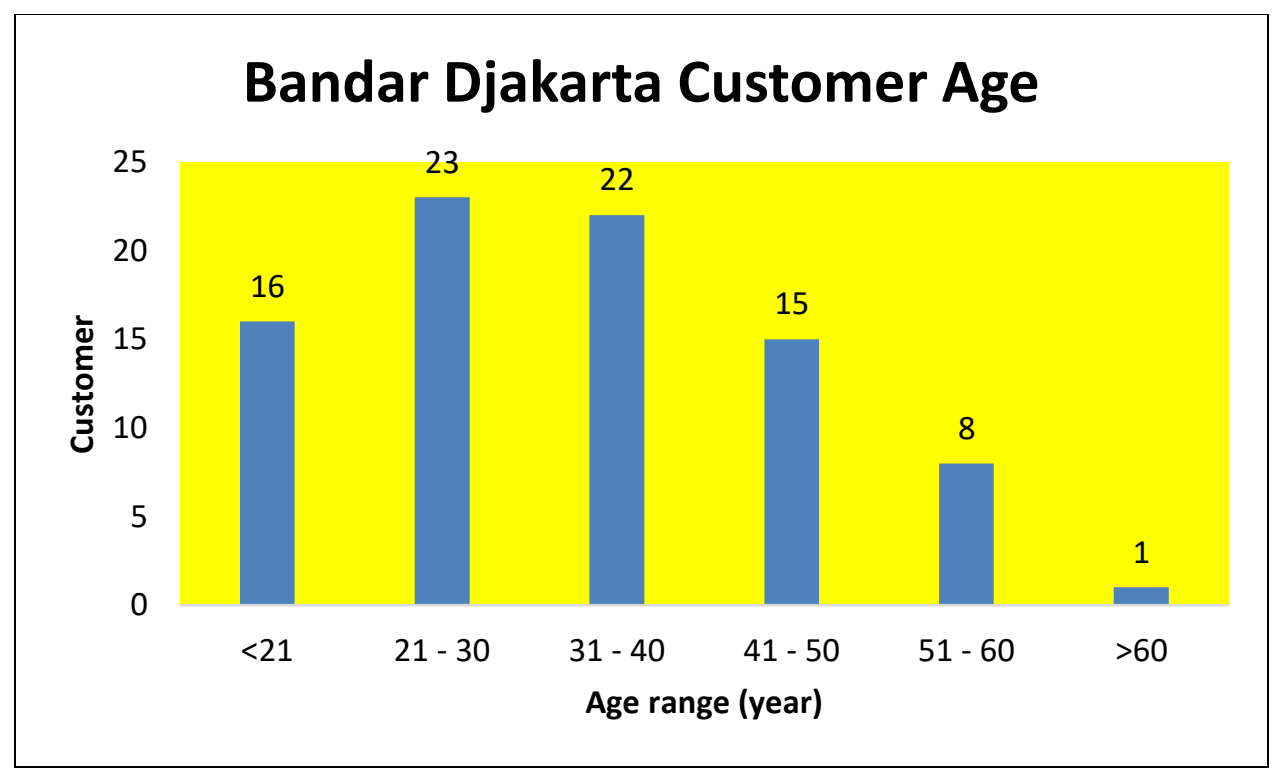

Figure 2. Consumer characteristics based on age

The most number of jobs chosen by respondents were 27 private employees. The number of respondents who chose self-employed as many as 16 people made these cond largest entrepreneur in the category of consumer work. 


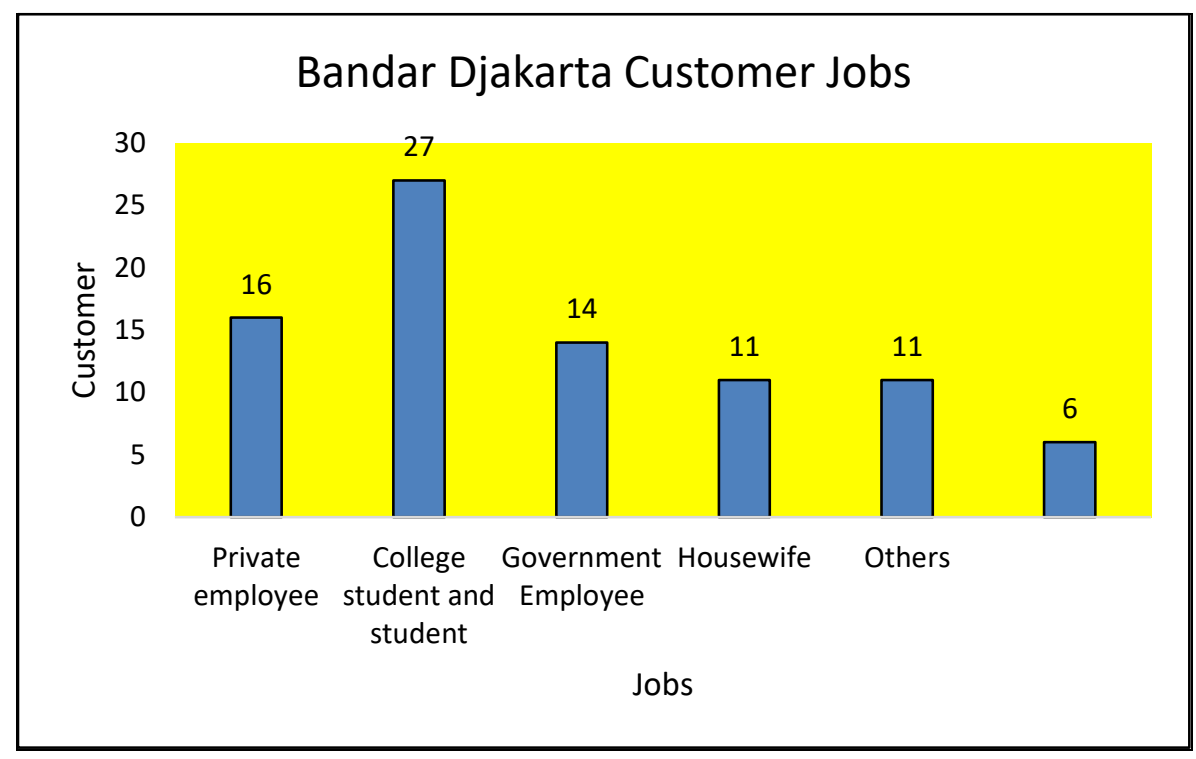

Figure 3. Consumer characteristics based on jobs

The number of family members 4 people is the most chosen category by 32 respondents, followed by 5 family members by 20 people.

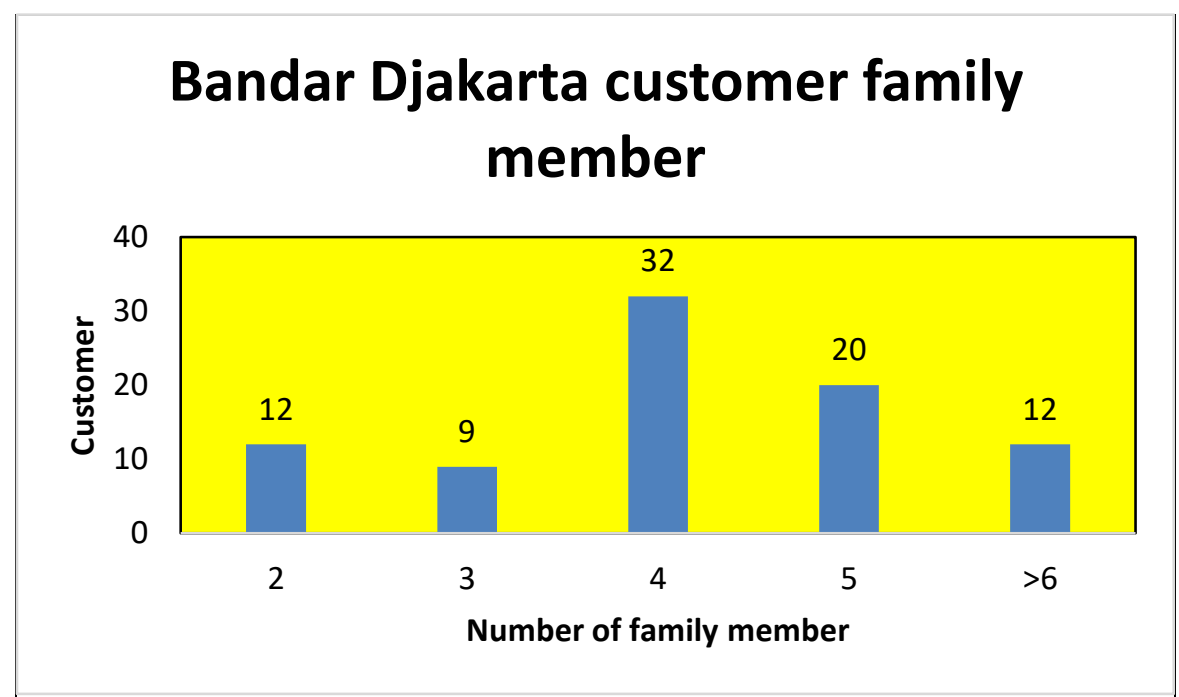

Figure 4. Consumer characteristics based on family members

The results obtained are the number of respondents living in Tangerang and Jakarta differing only by 1 respondent. The number of respondents who chose Tangerang as the domicile area was 34 people and those who chose Jakarta were 33 people 


\section{Bandar Djakarta customer residency}

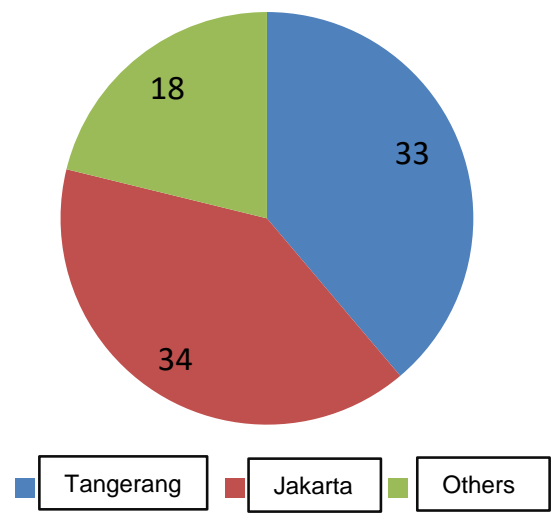

Figure 5. Consumer characteristics based on residency

Respondents who choose no income themselves are usually retirees, students, and students. The majority of respondents chose income > IDR. 4,000,000 with a total of 52 respondents and the lowest at IDR. 1,000,000 - 2,000.0000 with a total of 4 respondents.

\section{Bandar Djakarta customer residency}

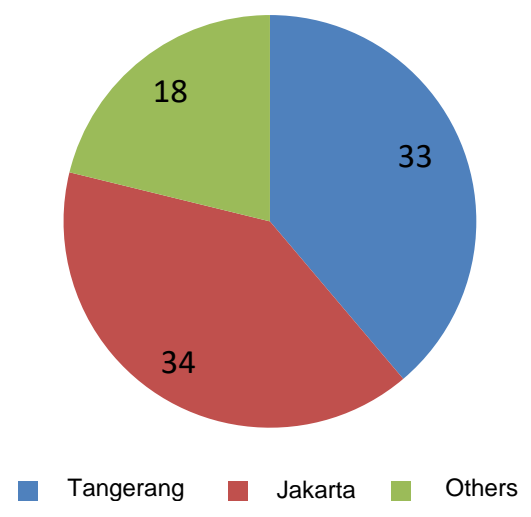

Figure 6.Consumer characteristics based on income

177 | The International Journal of Business Review (The Jobs Review) Vol.2 | No.2 | 2019 


\section{Importance Performance Analysis}

Bandar Djakarta Restaurant can find out which attributes need to be improved, reduced and maintained its performance by using one of the methods, the Importance Performance Analysis (IPA) method. Respondents' assessments of the level of importance and performance will be tabulated in the table below which is divided into 4 quadrants.

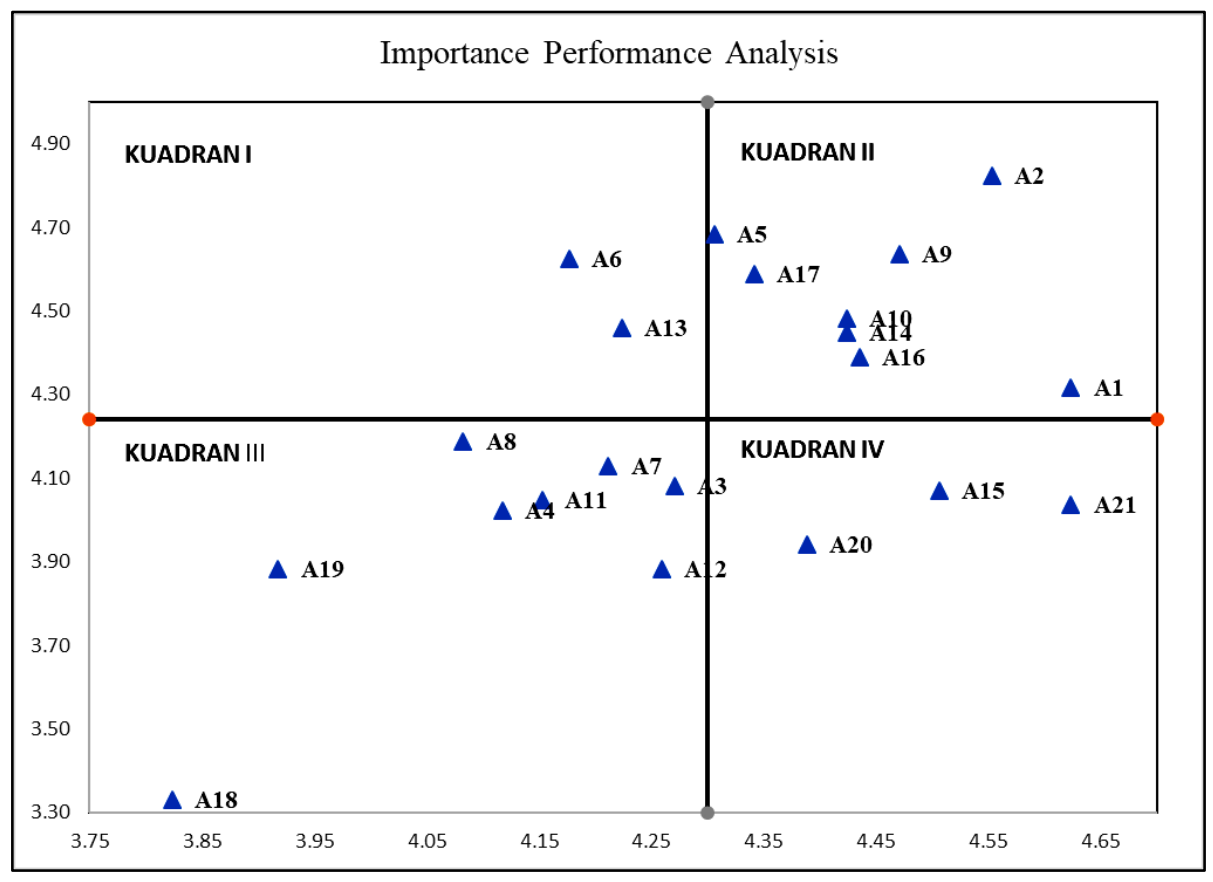

Figure 7. Importance Performance Analysis

Information

A1 Variation of food

A2 Food taste

A3 Food plating

A4 Nutrition content

A5 Food Cleanliness

A6 Equipment cleanliness

A7 Quantity of food

A8 Price

A9 Security Assurance

A10 Waiter hospitality

A11 Waiter's skill
A12 Waitress apperance

A13 speed of food served

A14 Queuing time

A15 Ease of Transaction

A16 Comfort of room

A17 Room cleanliness

A18 Entertaiment

A19 Facility

A20 Fish Market

A21 Location

First quadrant shows that Bandar Djakarta consumers have a high level of importance and expectations, but are low in the level of performance performed by Bandar Djakarta restaurants. Therefore, the attributes that exist in the first quadrant need to be improved and improved performance. Attributes classified in the first quadrant are:

a. A6 (food equipment)

b. A13 (Food serving speed)

178 | The International Journal of Business Review (The Jobs Review) Vol.2 |No.2|2019 
Second quadrant shows that consumers of the Bandar Djakarta restaurant have a high level of importance or expectations of the attributes that exist in this quadrant. The level of performance performed by the restaurant itself also has a high enough value so that the attributes in this quadrant are considered to be good. Therefore the attributes in this quadrant need to be maintained performance or achievement so that customer satisfaction is not reduced
a. A5 (Food hygiene)
b. A17 (Room Cleanliness)
c. A10 (Waiter's Hospitality)
d. A14 (Queue Time)
e. A16 (Room Comfort)
f. A9 (Security Guarantee)
g. A2 (Product Flavors)
h. A1 (Food Variations)

Third Quadrant shows that the attributes in this quadrant have a low level of importance followed by a low level of performance. The third Quadrant shows that the attributes are considered not special in the viewpoint of consumers. Therefore, it is necessary to consider whether the restaurant wants to make improvements to existing attributes. Improvements can be made if you have sufficient resources. Improvements also need to be done so that the attributes in the third quadrant do not move to the first quadrant and reduce customer satisfaction.
a. A18 (Entertainment)
b. A19 (General Facilities)
c. A8 (Food Price)
d. A4 (Nutrient content)
e. A11 (Waiter Skills)
f. A7 (Served Dish)
g. A3 (Serving Cuisine)
h. A12 (Waiter Appearances)

The fourth Quadrant is a quadrant that contains attributes that are considered less important by consumers but actually, those have a very good performance by the restaurant. The restaurant can reduce the performance of attributes in this quadrant to reduce the use of available resources. So that resources can be used to improve the quality of the attributes that are in the first quadrant. Based on this study, the attributes included in the fourth quadrant include:
a. A20 (Fish Market Facility)
b. A15 (Ease of Transaction)
c. A21 (Restaurant Location)

\section{Customer Satisfaction Index}

Consumer satisfaction index is a calculation of the level of overall customer satisfaction. Based on the calculation results, it is found CSI which is owned by Bandar Djakarta as a whole is at $\mathbf{8 5 . 0 0 \%}$. This shows that in general Bandar Djakarta Alam Sutera restaurant consumers are said to be very satisfied because they are in the range of values between $80 \%-100 \%$. Besides $85 \%$ also shows that there are still $15 \%$ of the problems that are considered by respondents to not satisfy them. 
Data collection using questionnaires to respondents carried out for 4 weeks in July 2019. Therefore CSI will be divided based on 4 weeks to find out which week consumers feel the most satisfied and vice versa. The figure below will tabulate the CSI values in weeks 1 through 4 in the Bandar Djakarta Alam Sutera restaurant.

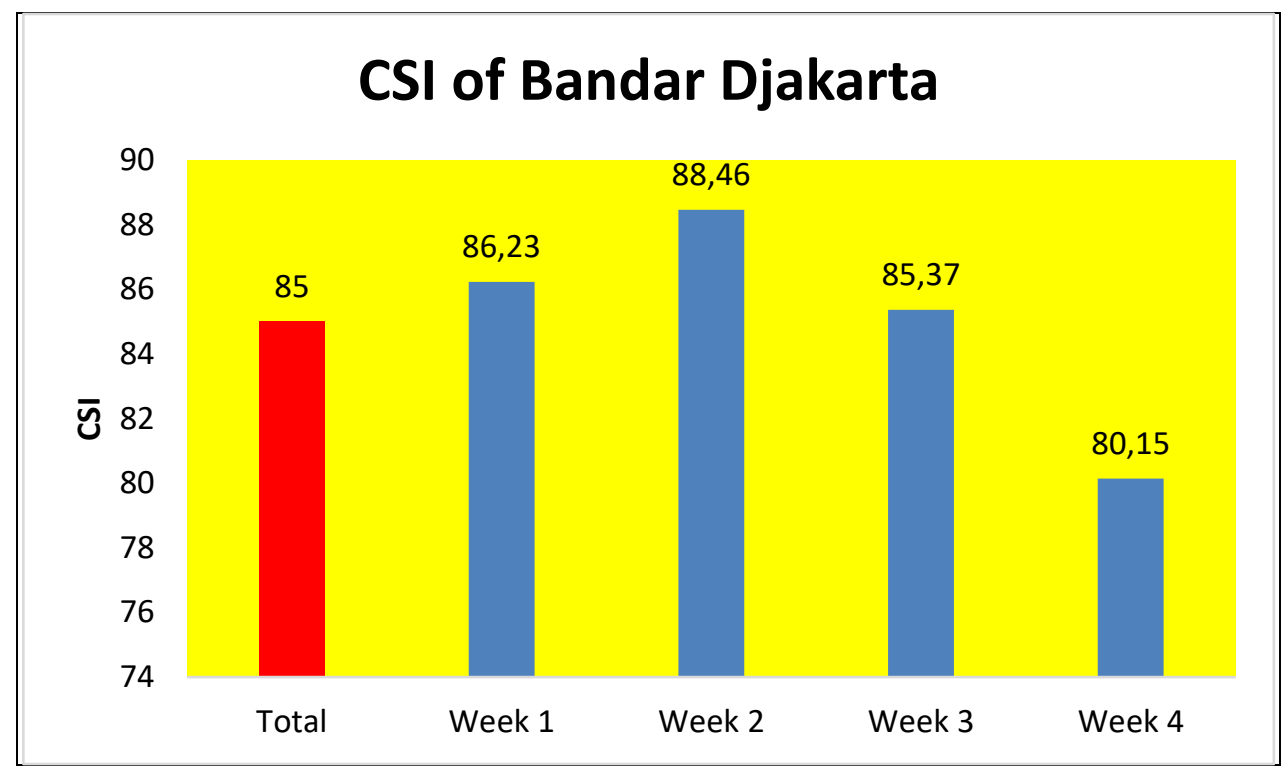

The highest customer satisfaction index (CSI) is at week 2 with a value of 88.46 and the lowest at week 4. A high CSI value at week 1 and week 2 is due in weeks 1 and 2 because the majority of respondents are private employees still have a new salary given at the beginning of the month. Satisfaction begins to decrease at the end of the month due to the lack of money they have. This is consistent with Tang's (1995) theory that people who have limited money can trigger anxiety and unhappiness.

\section{CONCLUSION}

Based on the results of research that has been carried out obtained several conclusions as follows (1) Attributes that affect customer satisfaction in Bandar Djakarta are divided into two, namely attributes that make consumers feel satisfied and consumers who make consumers feel less satisfied. The attributes that make consumers feel satisfied are the variety of food, product taste, food hygiene, security guarantees, the hospitality of the waitress, queuing time, room comfort and room cleanliness. While the attributes that make consumers feel less satisfied are the cleanliness of eating utensils and the speed at which food is served (2) The level of customer satisfaction Bandar Djakarta based on the results of the calculation of the customer satisfaction index get a total value of 85.00 which means that consumers of Bandar Djakarta are categorized very satisfied. The customer satisfaction index value is also seen based on the data collection week and the highest CSI value is at week 2 and lowest at week 4. 


\section{REFERENCES}

Aritonang. 2005. Kepuasan Pelanggan Pengukuran dan Penganalisisan dengan SPSS. Gramedia. Jakarta

Berggren, N. Time for behavioral political economy? An analysis of articles in behavioral economics. Rev. Austrian Econ. 25 (2012) 199-221

Cooke SJ, Lapointe NWR, Martins EG, Thiem JD, Raby GD, Taylor MK, Beard TD Jr, Cowx IG. Failure to engage the public in issues related to inland fishes and fisheries: strategies for building public and political will to promote meaningful conservation. J. Fish Biol. 83(4) (2013) 997-1018

Gujarati, DN. 2004. Basic Econometrics. 4th Edition, McGraw-Hill Companies.

Rizal A, Nurruhwati I, Khan AMA. (2019). Economic Contribution of Southern West Java Province Marine Fisheries. World Scientific News, 119 204-217

Rizal A, \& Nurruhwati I. (2019). New Methodological Approaches for Change in Traditional Sectors: The Case of the West Java Fisheries Socio Economic System. World News of Natural Sciences 22 41-51

Rizal A, Suryana AAH, Herawati H, Lantun PD, Izza MA. (2017). Regional Perspective To Build Competitiveness For Indonesian Fishery Sector In The Global And Autonomy Regime. Int. J. Agric. Env. Res. Vol 3 (6) 4368-4388

Rizal A. \& Nurruhwati I. (2018). Contribution of Human and Capital Toward Regional Economic Growth of Garut District of West Java Province of Indonesia. Global Scientific Journal, 6 (5) 172-179

Santoso, S. 2006. Menggunakan SPSS dan Excel untuk Mengukur Sikap dan Kepuasan Konsumen . Elex Media Komputindo. Jakarta

Tang, T. (1995). The Develpoment of Short Money Ethic Scale : Attitudes Toward Money and Pay Satisfaction Revisited. Indiv. Diff. Vol 19 No 6. 